\title{
FADD adaptor in cancer
}

\section{Léa Tourneur ${ }^{1}$, Agnès Buzyn ${ }^{1,2}$ and Gilles Chiocchia*1}

\begin{abstract}
Address: ${ }^{1}$ Département d'Immunologie, Institut Cochin, INSERM U 567, CNRS UMR 8104, IFR 116, Université René Descartes, Paris V, Paris, France and 2Service d'Hématologie Adultes, Hôpital Necker-Enfants Malades, Paris, France

Email: Léa Tourneur - tourneur@cochin.inserm.fr; Agnès Buzyn - buzyn@cochin.inserm.fr; Gilles Chiocchia* - chiocchia@cochin.inserm.fr

* Corresponding author
\end{abstract}

Published: 17 February 2005

Medical Immunology 2005, 4:I doi:10.1 186/1476-9433-4-I

This article is available from: http://www.medimmunol.com/content/4/I/I

(c) 2005 Tourneur et al; licensee BioMed Central Ltd.

This is an Open Access article distributed under the terms of the Creative Commons Attribution License (http://creativecommons.org/licenses/by/2.0), which permits unrestricted use, distribution, and reproduction in any medium, provided the original work is properly cited.
Received: 31 January 2005

Accepted: 17 February 2005

\begin{abstract}
FADD (Fas Associated protein with Death Domain) is a key adaptor molecule transmitting the death signal mediated by death receptors. In addition, this multiple functional protein is implicated in survival/proliferation and cell cycle progression. FADD functions are regulated via cellular sublocalization, protein phosphorylation, and inhibitory molecules. In the present review, we focus on the role of the FADD adaptor in cancer. Increasing evidence shows that defects in FADD protein expression are associated with tumor progression both in mice and humans. Better knowledge of the mechanisms leading to regulation of FADD functions will improve understanding of tumor growth and the immune escape mechanisms, and could open a new field for therapeutic interventions.
\end{abstract}

\section{The FADD molecule}

The FADD gene is located on chromosome 11q13.3 in humans and 7 in mice [1]. Mutations in the FADD gene containing locus are frequently observed in human malignancies [2]. For instance, the $11 \mathrm{q} 13$ region contains the fibroblast growth factor 3 and 4 genes which are coamplified in melanoma. It also includes the multiple endocrine neoplasia I gene whose mutation leads to tumor development of several endocrine glands including thyroid. Moreover, two genes implicated in leukemia are found in this locus: NUMA1 which is translocated in acute promyelocytic leukemia, and BCL1 which is located very close to the FADD gene and is mutated in B-cell leukemia/lymphoma. Although FADD has a central role in multiple receptor-induced cell death as discussed hereafter, no mutation of the FADD gene itself has been reported so far.

Human and mouse FADD genes have the same quite simple organization consisting of two exons (286 bp and 341 bp in humans; 332 bp and 286 bp in mice) separated by a unique intron of approximately $2 \mathrm{~kb}$. Interestingly, no cap site was reported on the human FADD mRNA [1], suggesting a particular regulation of FADD mRNA translation, although this topic has not been further investigated.

Human and mouse FADD proteins are very similar (Figure 1). They consist of 208 and 205 amino acids (AA) respectively, and share $80 \%$ similarity and $68 \%$ identity [3]. FADD mRNA and protein are almost ubiquitously expressed in fetal and adult tissues, both in humans and mice [4]. Two domains are particularly well conserved between species: the death domain (DD) at the $\mathrm{COOH}$ terminus of the protein, and the death effector domain (DED) at the NH2-terminus of the protein $[5,6]$. Both domains play a crucial role in transducing the apoptotic signal mediated by death receptors. Furthermore, a single serine (Ser) phosphorylation site essential for determining cell cycle progression is conserved in both species (human Ser 194 [7] and mouse Ser 191 [8]). 


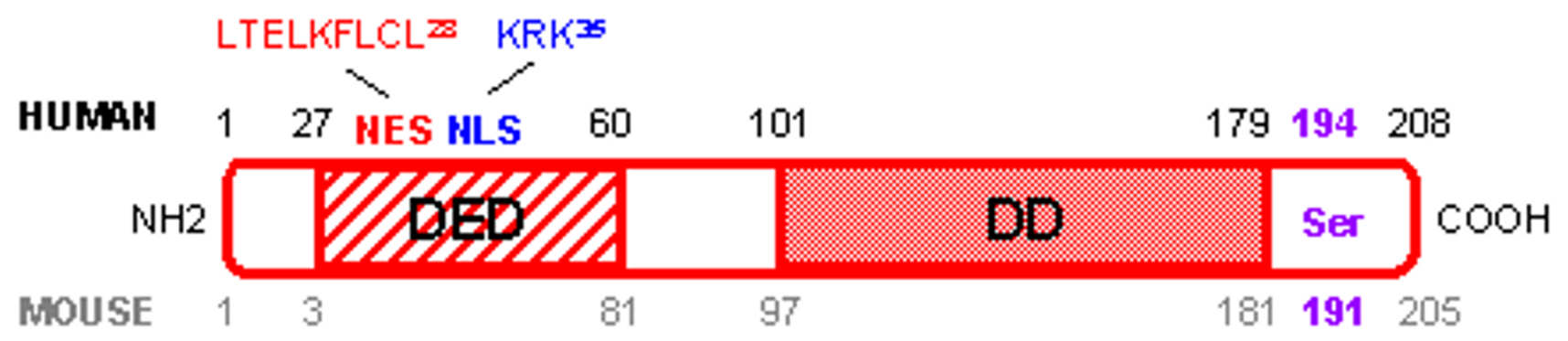

Figure I

Human and mouse FADD protein. Amino acids (AA) corresponding to the human FADD protein are marked in black, whereas AA corresponding to the mouse FADD protein are marked in grey. The death domain (DD) and death effector domain (DED) are essential for interaction with death receptors and transmission of the apoptotic signal. Human nuclear export sequence (NES in red) and nuclear localization sequence (NLS in blue) determine localization of the protein in the cytoplasm and the nucleus, which are associated with cell death and survival functions of the FADD protein, respectively. Human Ser 194 and mouse Ser 191 phosphorylation site (in purple) have a crucial role in survival/proliferation and cell cycle progression.

Since the first role ascribed to FADD was to transmit apoptotic signals through its interaction with death receptors expressed at the cell membrane, it was assumed that FADD protein was exclusively localized in the cytoplasm of the cell. However, a nuclear localization sequence (NLS) and a nuclear export sequence (NES) were recently identified in the human FADD protein (Figure 1), and account for FADD protein expression in the nucleus and the cytoplasm of the cell, respectively [9]. The vast majority of the reports on FADD focused on the cytoplasmic FADD protein because of its pro-apoptotic function. In contrast, the role of the nuclear FADD is much more mysterious. It was recently reported that FADD expression in the nucleus protects cells from apoptosis, but the mechanism implicated in this survival function has not been investigated [9]. On the other hand, it has been shown that FADD could interact within the nucleus of adherent cells with the methyl-CpG binding domain protein 4 (MBD4) [10]. MBD4 is a GT mismatch repairing protein. Association between MBD4 and FADD within the nucleus could couple MBD4-mediated genome surveillance with FADD-mediated cell death. Thus, nuclear FADD could perhaps have a pro-apoptotic function, at least in response to DNA-damaging agents.

\section{Functions of the FADD protein}

\section{An essential molecule for embryonic development}

The essential role of the FADD molecule was highlighted by generating FADD mutant null mice $[11,12]$. Indeed, FADD knockout mice were not viable. FADD null embryos died in utero at day 12.5 of development, due to underdevelopment, abdominal hemorrhage, and cardiac failure. Moreover, FADD loss of function did not result in a lymphoproliferative disorder as observed in viable Fas mutant mice $[13,14]$. These results indicated that in addition to its well known role in cell death, FADD was also implicated in survival/proliferation of some cell types.

\section{A main death transducer for DD-containing receptors}

FADD is the main signal transducing intermediate adaptor molecule of several death receptors including Fas, TNF-R1 (tumor necrosis factor receptor 1), DR3 (death receptor 3), TRAIL-R1 (TNF-related apoptosis-inducing ligand, DR4), and TRAIL-R2 (DR5) $[4,11,12,15]$. All these receptors possess, in their intra-cytoplasmic tail, a DD homologous to the DD of FADD allowing FADD recruitment to the activated receptor. FADD can be recruited either directly to Fas and TRAIL-Rs (Figure 2A) or indirectly to TNF-R1 (Figure 2B). In the latter case, FADD is recruited via another DD-containing adaptor molecule (TRADD, TNF receptor-associated protein with DD). Next, FADD recruits DED-containing initiator pro-caspase 8 or 10 through DED/DED interactions [16-18], thus forming the death-inducing signaling complex (DISC) [19]. Autoprocessing of initiator pro-caspase leads to activation of effective caspases which cleave intracellular substrates, causing the apoptotic death of the cell $[20,21]$.

Control of FADD recruitment to the DISC can occur following several mechanisms depending on the cell type and the death receptor [22]. The best characterized death receptor signaling inhibitors are DED-containing viral and cellular FLICE-inhibitory proteins (v-FLIPs and cFLIPs, respectively) $[23,24]$. Inhibition of Fas-, TNF-R1-, and TRAIL-Rs-induced apoptosis by endogenous FLIPs results from binding of the c-FLIPs to the DED of FADD, 
A.

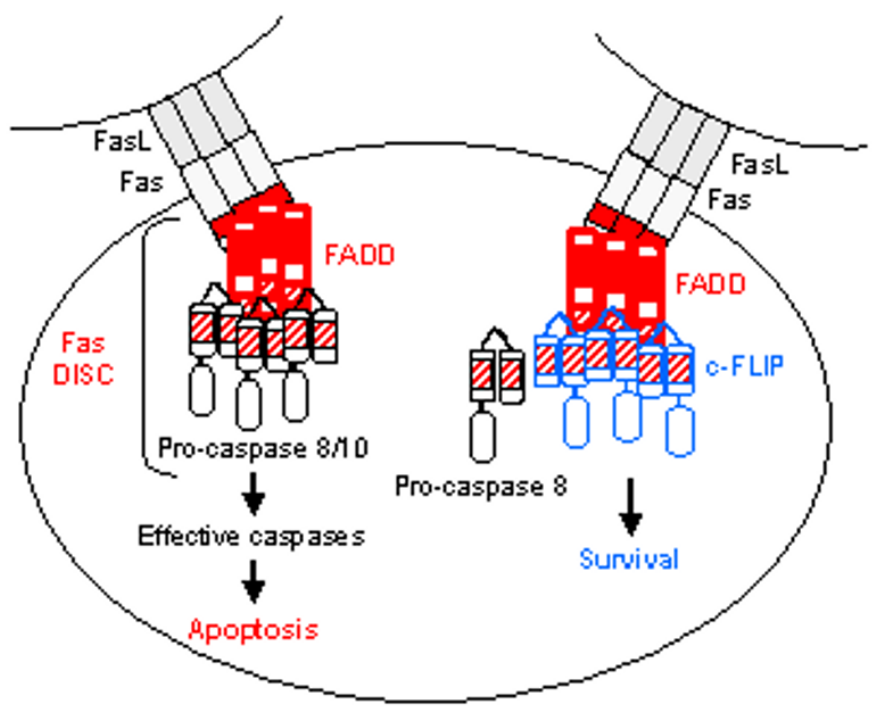

B.

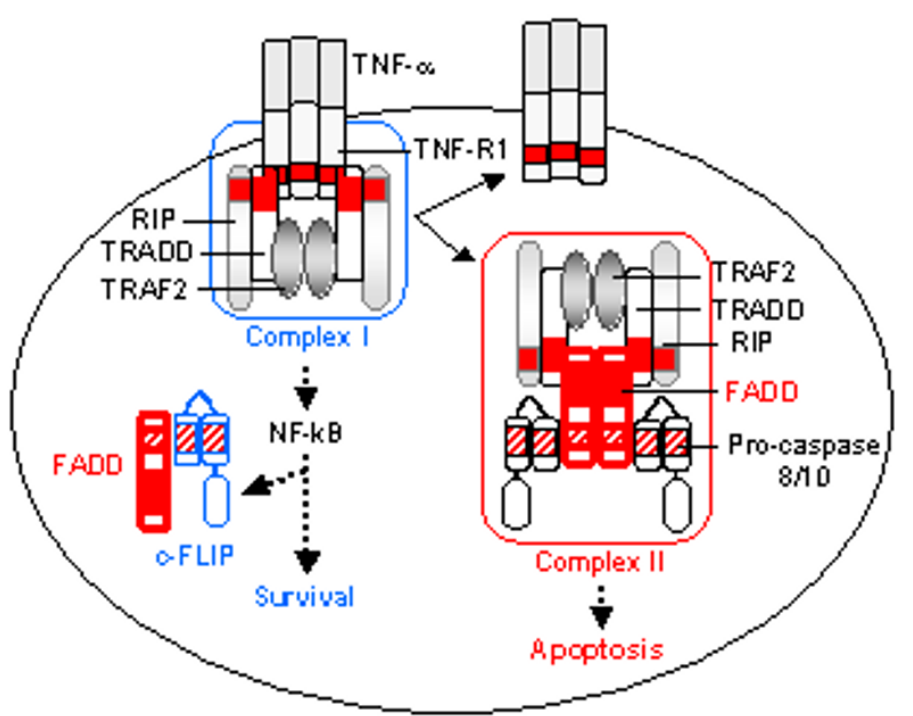

\section{Figure 2}

Apoptosis mediated by death receptors requires the FADD adaptor molecule. (A) Engagement of a Fas ligand trimer on a trimer of Fas leads to FADD adaptor molecule recruitment through homotypic DD interactions. FADD next binds initiator pro-caspase through DED interactions. This Fas/FADD/pro-caspase complex forms the Fas death-inducing signaling complex (DISC) since initiator pro-caspase activates a caspase cascade resulting in apoptotic death of the cell. Alternatively, cFLIPs can promote cell survival by interacting with FADD through their respective DED, thus hindering recruitment and activation of initiator pro-caspase. (B) Signaling mediated by TNF-RI implicates formation of two sequential complexes [6I]. The complex I (in blue) contains the TNF-RI, the adaptor TRADD, the receptor interacting kinase (RIP), and the TNF-receptor associated factor 2 (TRAF2). It assemblies rapidly following TNF- $\alpha$ stimulation and activates the NF-kB pathway which in turn induces expression of survival genes, including c-FLIP. Later on, complex I dissociates from the TNF-RI and is internalized. FADD can then bind the liberated DD of TRADD and recruits initiator pro-caspase, forming complex II (in red) which is cytoplasmic. Activation of initiator pro-caspase $8 / 10$ in complex II results in apoptosis of the cell. Red box: DD; hatched red box: DED. 
thus hindering pro-caspase 8 activation (Figure 2A). Similarly, v-FLIPs inhibit apoptosis mediated by death receptors either by binding to FADD and blocking pro-caspase 8 processing, or by binding to pro-caspase 8 and inhibiting FADD interaction. Therefore, equilibrium between FADD and the expression of its inhibitors determines the outcome of the death receptor-stimulated cell, i.e. apoptosis or survival.

All the main death receptors described up to now require FADD adaptor for transmitting their apoptotic signal. Consequently, FADD is a central protein that controls multiple essential cellular processes including cellular homeostasis and elimination of pathological cells, particularly during the course of an immune response.

\section{Death receptor independent FADD induced apoptosis}

Formation of cytoplasmic death effector filaments (DEF) by oligomerization of DED-containing proteins, including FADD, is responsible for death receptor independent cellular apoptosis [25]. Indeed, FADD over-expression by itself is known to induce cell death through DEF formation that recruits and activates pro-caspase 8 . However, the existence of DEF has not been established in vivo, and increasing evidences suggest that DEF could be artefactual structures resulting from protein over-expression. As a consequence, the ability of endogenous FADD to aggregate and form DEF in normal situation should be reconsidered.

\section{Functions in proliferation and cell cycle progression}

Beside being a main death adaptor molecule, FADD is also required for $\mathrm{T}$ cell proliferation. The first evidence of this property of FADD came from observations made in chimeric FADD knockout mice. Five-week-old chimeric FADD $/$ - mice presented a lack of thymocytes compared to wild type animals, with few or no $\mathrm{CD} 4{ }^{+} \mathrm{CD} 8+$ double positive thymocytes remaining [12]. Moreover, several groups have demonstrated that FADD deficiency in peripheral T lymphocytes resulted in an inhibition of mitogeninduced $\mathrm{T}$ cell proliferation [12,26-30]. The mechanism leading to FADD-dependent $\mathrm{T}$ cell proliferation did not involve the early events associated with cell proliferation since expression level and functionality of the IL-2 receptor, level of IL-2 secretion, mobilization of intracellular calcium, and activation of NF-kB, p38-MAPK, and p44/ 42-MAPK appeared normal in FADD $/-\mathrm{T}$ lymphocytes $[12,29,30]$. Recent data showed that FADD $/-$ T lymphocytes entered the cell cycle upon mitogenic stimulation, but died during progression through the cell cycle [30]. Therefore, lack of proliferation of FADD-deficient $\mathrm{T}$ cells results from defective survival associated with progression through the cell cycle rather than defective activation. Up to now, the molecular pathway implicated in
FADD-mediated survival of lymphocytes has not been described.

In addition to impairing survival during cell division, FADD deficiency also leads to a dysregulation of the cell cycle machinery [31]. The pattern of expression of molecules implicated in both G1/S and G2/M transitions was aberrant in $\mathrm{FADD}^{-/}$lymphocytes, resulting in spontaneous entry and progression through the cell cycle of $10 \%$ of freshly isolated FADD $/$ - T cells (as compared to less than $2 \%$ of wild type T cells) [31].

The mechanisms responsible for FADD regulation of cell cycle progression are not fully understood. However, the phosphorylation of the 194 human and 191 mouse Ser of the protein (Figure 1) has recently drawn attention. Indeed, human FADD was phosphorylated at Ser 194, by a still unidentified $70 \mathrm{kDa}$ protein kinase, in cells arrested in G2/M, whereas it was unphosphorylated in G1/S [7]. Generation of FADD Ser 191 mutant mice confirmed that FADD phosphorylation is involved in proliferation in vivo [8]. Replacement of Ser 191 by an aspartic acid resulting in constitutive phosphorylation of the FADD protein led to abnormal development of FADD mutant mice that shared the same phenotype as FADD deficient mice [8], including few $\mathrm{CD} 4+{ }^{+} \mathrm{CD} 8+$ thymocytes and defective progression through the cell cycle $[12,31]$.

Tumor cells are constantly cycling cells. Although it does not seem to directly affect the cell cycle progression, FADD phosphorylation at Ser 194 sensitizes these cells to reagents that induce $\mathrm{G} 2 / \mathrm{M}$ arrest such as the Taxol anticancer drug [32]. In human prostate cancer cell lines, treatment with Taxol resulted in Ser 194 FADD phosphorylation and G2/M arrest [33]. Moreover, etoposide or cisplatin chemotherapeutic drug-induced apoptosis of these cells was enhanced by pretreatment with Taxol, a process that was inhibited by cellular over-expression of an unphosphorylable FADD mutant [33]. Therefore, tumor cells that express a Ser 194 FADD mutant that cannot be phosphorylated or are unable to phosphorylate FADD at this Ser position are expected to resist apoptosis induced by anticancer drugs that induce G2/M arrest, and to be insensitive to the synergistic effect of chemotherapy. Obviously, a lack of FADD expression will have the same consequences.

\section{Role in tumor development FADD as a tumor suppressor}

The role of the FADD adaptor in cancer was initially demonstrated by generating RAG-1 deficient transgenic mice that target expression of a FADD dominant negative mutant in lymphocytes. With age these mice developed thymic lymphoblastic lymphoma, whereas FADD+/+ RAG$1 \%$ mice did not [34]. Moreover, thymic lymphoblastic 
lymphomas were never observed in $\mathrm{FADD} /-\mathrm{RAG}-1^{+/+}$or FADD $/-$ RAG-1+/- mice, demonstrating that absence of FADD expression was necessary but not sufficient to induce tumor development in this model [34]. These results were the first demonstration that FADD adaptor can act as a tumor suppressor in vivo.

Using a mouse model of thyroid adenoma/adenocarcinoma, we showed spontaneous disappearance of FADD protein expression during the course of tumor development [35]. The so called gsp transgenic mice expressed an oncogene specifically in thyroid follicular cells (TFC), and developed thyroid hyperplasia that eventually transformed into hyperfunctioning adenomas or adenocarcinomas around the age of 8 months [36]. The fact that gsp mice developed hyperfunctioning adenomas or adenocarcinomas belatedly suggested that oncogene expression conferred a predisposition but that an additional event was necessary for thyroid tumor development. We found that FADD protein was highly expressed in all non-pathological and in almost all hyperplastic thyroid glands from gsp mice. In contrast, thyroid adenoma/adenocarcinoma expressed low or no FADD protein [35]. These results raised the possibility that loss of FADD protein expression could be an additional event contributing to tumorigenesis, and suggested that FADD plays a role as a tumor suppressor.

We recently showed that absence of FADD protein expression in cancer cells is also a relevant phenomenon in human malignancies [37]. We looked for FADD protein expression in human acute myeloid leukemia (AML) cells. Leukemic cells of most AML patients are resistant to Fasmediated cell death despite expressing the Fas receptor [38] and/or the FasL molecule [39]. Moreover, chemotherapeutic drugs used for AML treatment can kill target cells via several mechanisms, including death receptorinduced apoptosis [40-43]. We performed a retrospective study of 70 consecutive patients with de novo AML treated homogeneously, and found that leukemic cells of 2/3 of patients at diagnosis expressed low or no FADD protein [37]. Moreover, in this cohort of patients, we showed that absent/low FADD protein expression in AML cells at diagnosis was a new independent prognostic factor for poor response to chemotherapy (in terms of complete remission rate, event free and overall survivals) [37]. Importantly, absent/low FADD protein expression in AML cells at diagnosis was a prognostic factor even for patients classified as standard- or good-risk AML cases by cytogenetic and molecular criteria [37]. As a consequence, this new prognostic factor is of clinical importance since it will allow early identification of patients with chemoresistant AML who could benefit from more intensive post-remission therapy.

\section{Absence of FADD confers numerous advantages on cancer cells}

The fact that absence of FADD expression was found in different types of tumor cells both in mice and humans strongly suggested that absence of FADD contributed to tumor development. Indeed, lack of FADD protein can confer numerous advantages on pathological cells, which predominantly result in tumor survival/growth gain (Figure 3).

\section{Immune escape and resistance to chemotherapy}

Fas, TRAIL-Rs, TNF-R1, DR3, and potentially other receptors use FADD adaptor for transmitting the death signal. Thus, absence of FADD expression in tumor cells must confer multiple resistance of these cells to death receptor cytotoxicity. In agreement with this assumption, we observed that FADD $\%$ TFC as well as FADD $/$ AML cells were resistant to Fas- and TNF- $\alpha$-mediated apoptosis [35], and unpublished data). Since cytotoxic tumor infiltrating lymphocytes (TIL) use, among other mechanisms, death receptor-mediated cell death to kill pathological cells, tumor cells lacking FADD molecule expression may partially avoid immune attack (Figure 3A). On the other hand, some anticancer drugs exert their cytotoxic effect by inducing death receptor and/or death ligand expression on tumor cells, thereby inducing suicidal/fratricidal apoptosis of the cells. For instance, anthracyclines and etoposide, two chemotherapeutic drugs used for AML treatment, enhance Fas- and TRAIL-R2-mediated cell death in vitro, a process requiring FADD molecule expression $[40-42,44,45]$. As a consequence, absence of FADD expression in AML cells of our patients may contribute to chemoresistance of leukemic cells (Figure 3A).

\section{Tumor counter-attack}

As described above, absence of FADD allows co-expression of death receptors and ligands without inducing autocrine or paracrine apoptosis of tumor cells. For instance, although the Fas receptor was expressed at all stages of thyroid tumor development in gsp mice, FasL expression was gained with a high expression in adenomatous/adenocarcinomatous glands [35]. Using the same method, we found that leukemic cells of most AML patients expressed FasL [39] and secreted TNF- $\alpha$ despite expressing Fas and TNF-R1 [37], and unpublished data). Moreover, co-expression of Fas and FasL molecules that did not cause cell death was also observed in lymphoma [46], melanoma [47], astrocytoma [48], cancers of the colon [49], liver [50], lung [51], human thyroid [52]. The role of death ligand expression in tumor cells is still a controversial issue [53-55], but it is now well accepted that it allows at least some cancer cells to kill TIL that express death receptors, a process called the "tumor counterattack" (Figure 3B). 
A.

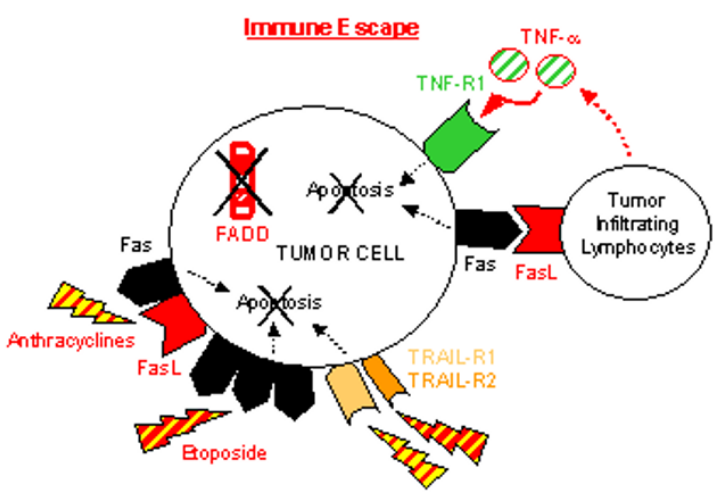

Resistance to Chemotherapy

B.

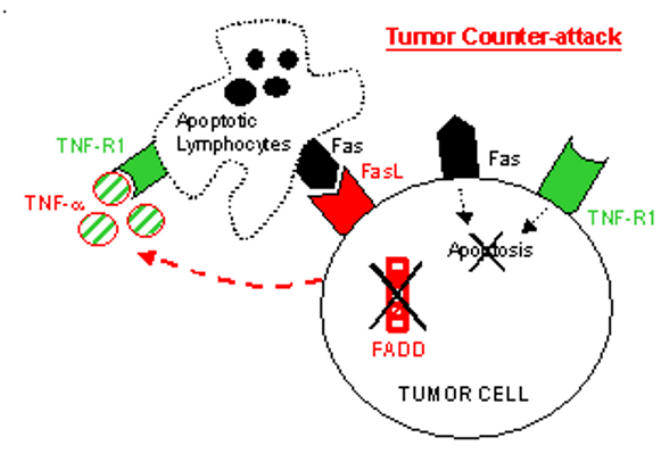

C.

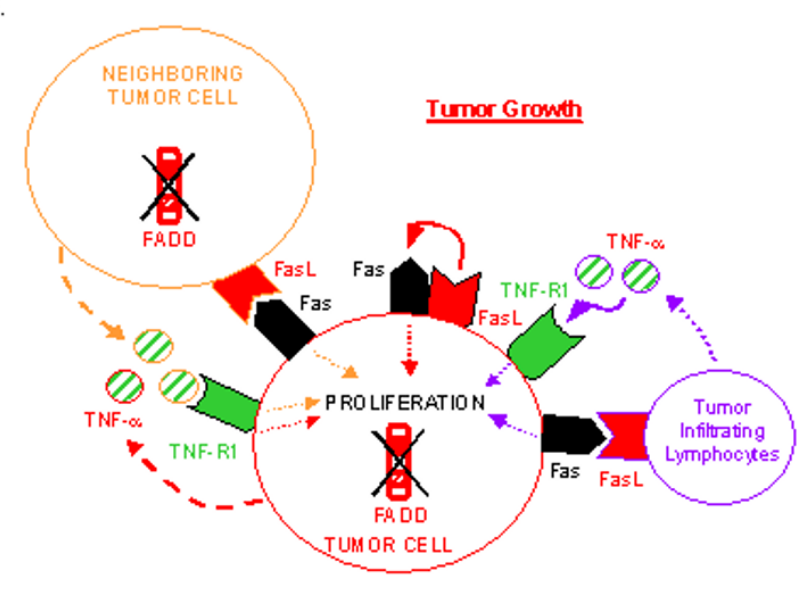

\section{Figure 3}

Lack of FADD expression confers survival/growth advantages on tumor cells. Absence of FADD protein confers multiple death receptor-mediated apoptosis resistance and allows tumor cells to co-express death receptors and ligands without committing cell death. (A) Lack of FADD contributes to immune escape and resistance to chemotherapy. FADD deficient tumor cells resist death receptor-mediated apoptosis induced by TIL and chemotherapeutic drugs. Anthracyclines increase Fas and FasL expression on tumor cells. Etoposide induces Fas receptor trimerization, leading to Fas-mediated cell death independently of FasL expression. Both drugs enhance TRAIL-R2-mediated apoptosis. (B) Lack of FADD contributes to tumor counterattack. Lack of FADD expression allows many types of tumor cells to express innocuously functional FasL that can kill TIL. Secretion of TNF- $\alpha$ by AML cells can have cytotoxic effects on TIL. (C) Lack of FADD contributes to tumor growth. In the absence of FADD, Fas signaling leads to a proliferative signal instead of an apoptotic one. Concomitant death receptor and ligand expression, in the absence of FADD, allows autocrine (in red) and paracrine (in orange) proliferation of tumor cells. Activated TIL can contribute to paracrine (in purple) proliferation of FADD-deficient tumor cells. 


\section{Proliferative advantage}

Since the tumor counter-attack hypothesis cannot apply to all types of cancer cells, one could wonder whether other benefits of death ligand expression by tumor cells exists. Previous reports demonstrated that Fas signaling could lead to proliferation instead of apoptosis, depending on the cell type and the environmental conditions [56-58]. For instance, agonistic anti-Fas antibody-induced proliferation of hematological and non-hematological tumors has been described [59]. Moreover, we have shown that stimulation of FADD lacking thyrocytes by an agonistic anti-Fas antibody resulted in accelerated growth of TFC, via a particular Daxx adaptor-mediated pathway [35]. Therefore, Fas signaling, particularly in the absence of FADD, can confer proliferative advantage on tumor cells (Figure 3C). Thus, FasL expression on Fas $^{+}$FADDadenomatous/adenocarcinomatous thyroid from gsp mice, as well as on human AML cells, may allow both autocrine and paracrine proliferation of these cells [35,37] (Figure 3C). Furthermore, we can formulate the same hypothesis for TNF- $\alpha$ secretion by TNF-R1 expressing leukemic cells (Figure 3C). If our hypotheses are correct, then activated TIL that express death ligands could contribute to FADD-deficient tumor proliferation (Figure 3C).

\section{Restoring FADD protein expression- a new therapeutic issue}

Absence of FADD expression could confer multiple growth advantages on cancer cells (Figure 3), and is expected to contribute to disease progression. As a consequence, finding how to restore FADD protein expression in FADD-negative tumor cells represents a research field with potentially direct clinical applications. In fact, it is possible that some of the current cancer treatments act, at least partially, through this mechanism. For instance, carboplatin is a cytotoxic drug potentially effective at reestablishing functional FADD protein expression. Indeed, the human tongue carcinoma cell lines SCC-9 and SCC-25 express very low levels of FADD protein. Moreover, treatment with carboplatin enhances FADD protein expression, thus rendering cancer cells sensitive to Fas-mediated apoptosis [60]. The combination of carboplatin with chemotherapeutic drugs that induce death receptor-mediated cell death may result in improved treatment.

Molecules implicated in FADD regulation of expression also represent new therapeutic targets. However, very little is known about the mechanisms leading to absent/low FADD protein expression in tumor cells. In SCC-9 and SCC-25 carcinoma cell lines, carboplatin upregulated FADD protein expression by increasing FADD mRNA [60]. However, FADD mRNA was normally expressed in mouse thyroid adenoma/adenocarcinoma and in human AML cells, and lack of FADD mRNA could not account for poor FADD protein expression in these cancer cells $[35,37]$. These results suggest that several mechanisms could be implicated in loss of FADD protein, depending on the type of cell and the environmental pressure. Besides, docking FADD protein away from the death receptor, in the nucleus for example, would have the same consequences. Understanding such mechanisms is the first necessary step towards development of new anticancer drugs targeting molecules that regulate FADD protein expression.

\section{Conclusion}

FADD is mainly known as a key adaptor molecule for numerous death receptors. However, increasing evidences have shown that FADD is a much more complex molecule implicated in apoptosis, survival, cell cycle progression, and proliferation of the cells. Therefore, FADD plays a central role in the frightening control of cell death and life. As a consequence, a defect in the FADD molecule can contribute to the development of diseases, and particularly cancer. Absence of FADD protein expression is a marker of tumor development in the mouse, and a prognostic factor for poor response to chemotherapy in humans. Since FADD deficiency could contribute to several malignancies, in view of its almost ubiquitous pattern of expression, study of the role of FADD in tumor development, growth, and resistance to treatment, and understanding how the expression of this puzzling molecule is regulated, are targets that merit further investigation.

\section{Authors' Contributions}

LT conceived the review and drafted the manuscript. GC participated in conceiving the review. AB and GC participated in the preparation of the manuscript. All authors read and approved the final manuscript.

\section{Acknowledgments}

LT is a recipient of a "Société Française d'Hématologie" (SFH) post-doctoral training fellowship. This work was supported by the Institut National de la Santé Et de la Recherche Médicale (INSERM).

\section{References}

I. Kim PK, Dutra AS, Chandrasekharappa SC, Puck JM: Genomic structure and mapping of human FADD, an intracellular mediator of lymphocyte apoptosis. J Immunol 1996, 157:546I-5466

2. Katoh M: FLJ1026I gene, located within the CCNDI-EMSI locus on human chromosome $\mathrm{IIqI}$, encodes the eighttransmembrane protein homologous to CI 2 orf3, CI lorf25 and FLJ34272 gene products. Int J Oncol 2003, 22: I375-I38I.

3. Zhang J, Winoto A: A mouse Fas-associated protein with homology to the human Mort I/FADD protein is essential for Fas-induced apoptosis. Mol Cell Biol 1996, 16:2756-2763.

4. Chinnaiyan AM, O'Rourke K, Tewari M, Dixit VM: FADD, a novel death domain-containing protein, interacts with the death domain of Fas and initiates apoptosis. Cell 1995, 81:505-5 I2.

5. Weber $\mathrm{CH}$, Vincenz $\mathrm{C}$ : The death domain superfamily: a tale of two interfaces? Trends Biochem Sci 200I, 26:475-48I.

6. Eberstadt M, Huang B, Chen Z, Meadows RP, Ng SC, Zheng L, Lenardo MJ, Fesik SW: NMR structure and mutagenesis of the 
FADD (MortI) death-effector domain. Nature 1998, 392:94I-945.

7. Scaffidi C, Volkland J, Blomberg I, Hoffmann I, Krammer PH, Peter ME: Phosphorylation of FADD/ MORTI at serine I 94 and association with a $70-\mathrm{kDa}$ cell cycle-regulated protein kinase. J Immunol 2000, 164:I236-I242.

8. Hua ZC, Sohn SJ, Kang C, Cado D, Winoto A: A function of Fasassociated death domain protein in cell cycle progression localized to a single amino acid at its C-terminal region. Immunity 2003, 18:513-52I.

9. Gomez-Angelats $M$, Cidlowski JA: Molecular evidence for the nuclear localization of FADD. Cell Death Differ 2003, 10:79|-797.

10. Screaton RA, Kiessling S, Sansom OJ, Millar CB, Maddison K, Bird A, Clarke AR, Frisch SM: Fas-associated death domain protein interacts with methyl-CpG binding domain protein 4: a potential link between genome surveillance and apoptosis. Proc Natl Acad Sci U S A 2003, 100:52 I I-52 I6.

II. Yeh WC, Pompa JL, McCurrach ME, Shu HB, Elia AJ, Shahinian A, Ng M, Wakeham A, Khoo W, Mitchell K, El-Deiry WS, Lowe SW, Goeddel DV, Mak TW: FADD: essential for embryo development and signaling from some, but not all, inducers of apoptosis. Science 1998, 279:1954-1958.

12. Zhang J, Cado D, Chen A, Kabra NH, Winoto A: Fas-mediated apoptosis and activation-induced $\mathrm{T}$-cell proliferation are defective in mice lacking FADD/MortI. Nature 1998 , 392:296-300.

13. Watanabe-Fukunaga $\mathrm{R}$, Brannan $\mathrm{Cl}$, Copeland NG, Jenkins NA, Nagata S: Lymphoproliferation disorder in mice explained by defects in Fas antigen that mediates apoptosis. Nature 1992 356:314-317.

14. Adachi M, Suematsu S, Kondo T, Ogasawara J, Tanaka T, Yoshida N, Nagata S: Targeted mutation in the Fas gene causes hyperplasia in peripheral lymphoid organs and liver. Nat Genet 1995 I I:294-300.

15. Kuang AA, Diehl GE, Zhang J, Winoto A: FADD is required for DR4- and DR5-mediated apoptosis: lack of trail-induced apoptosis in FADD-deficient mouse embryonic fibroblasts. J Biol Chem 2000, 275:25065-25068.

16. Nagata S: Apoptosis by death factor. Cell 1997, 88:355-365.

17. Kischkel FC, Lawrence DA, Tinel A, LeBlanc H, Virmani A, Schow P, Gazdar A, Blenis J, Arnott D, Ashkenazi A: Death receptor recruitment of endogenous caspase- 10 and apoptosis initiation in the absence of caspase-8. I Biol Chem 200I, 276:46639-46646.

18. Wang J, Chun HJ, Wong W, Spencer DM, Lenardo MJ: Caspase-I0 is an initiator caspase in death receptor signaling. Proc Natl Acad Sci U S A 200I, 98: I3884-13888.

19. Kischkel FC, Hellbardt S, Behrmann I, Germer M, Pawlita M, Krammer PH, Peter ME: Cytotoxicity-dependent APO-I (Fas/ CD95)-associated proteins form a death-inducing signaling complex (DISC) with the receptor. Embo J 1995, 14:5579-5588.

20. Muzio M, Chinnaiyan AM, Kischkel FC, O'Rourke K, Shevchenko A, $\mathrm{Ni}$ J, Scaffidi C, Bretz JD, Zhang M, Gentz R, Mann M, Krammer PH, Peter ME, Dixit VM: FLICE, a novel FADD-homologous ICE CED-3-like protease, is recruited to the CD95 (Fas/APO-I) death--inducing signaling complex. Cell 1996, 85:8I7-827.

21. Martin DA, Siegel RM, Zheng L, Lenardo MJ: Membrane oligomerization and cleavage activates the caspase-8 (FLICE/ MACHalphal) death signal. J Biol Chem 1998, 273:4345-4349.

22. Tibbetts MD, Zheng L, Lenardo MJ: The death effector domain protein family: regulators of cellular homeostasis. Nat Immunol 2003, 4:404-409.

23. Thome M, Schneider P, Hofmann K, Fickenscher H, Meinl E, Neipel F, Mattmann C, Burns K, Bodmer JL, Schroter M, Scaffidi C, Krammer $\mathrm{PH}$, Peter ME, Tschopp J: Viral FLICE-inhibitory proteins (FLIPs) prevent apoptosis induced by death receptors. Nature 1997, 386:5|7-521.

24. Irmler M, Thome M, Hahne M, Schneider P, Hofmann K, Steiner V Bodmer JL, Schroter M, Burns K, Mattmann C, Rimoldi D, French LE, Tschopp J: Inhibition of death receptor signals by cellular FLIP. Nature 1997, 388:190-195.

25. Siegel RM, Martin DA, Zheng L, Ng SY, Bertin J, Cohen J, Lenardo MJ: Death-effector filaments: novel cytoplasmic structures that recruit caspases and trigger apoptosis. J Cell Biol 1998, 141:1243-1253.
26. Newton K, Harris AW, Bath ML, Smith KG, Strasser A: A dominant interfering mutant of FADD/MORTI enhances deletion of autoreactive thymocytes and inhibits proliferation of mature T lymphocytes. Embo | 1998, |7:706-7|8.

27. Kabra NH, Kang C, Hsing LC, Zhang J, Winoto A: T cell-specific FADD-deficient mice: FADD is required for early $T$ cell development. Proc Natl Acad Sci U S A 200I, 98:6307-63I2.

28. Strasser A, Newton K: FADD/MORTI, a signal transducer that can promote cell death or cell growth. Int J Biochem Cell Biol 1999, 31:533-537.

29. Newton K, Kurts C, Harris AW, Strasser A: Effects of a dominant interfering mutant of FADD on signal transduction in activated T cells. Curr Biol 200I, I I:273-276

30. Beisner DR, Chu IH, Arechiga AF, Hedrick SM, Walsh CM: The requirements for Fas-associated death domain signaling in mature T cell activation and survival. J Immunol 2003, | 7 |:247-256.

31. Zhang J, Kabra NH, Cado D, Kang C, Winoto A: FADD-deficient $T$ cells exhibit a disaccord in regulation of the cell cycle machinery. J Biol Chem 200I, 276:298I 5-298I8.

32. Alappat EC, Volkland J, Peter ME: Cell cycle effects by C-FADD depend on its C-terminal phosphorylation site. J Biol Chem 2003, 278:4I 585-4I588.

33. Shimada K, Matsuyoshi S, Nakamura M, Ishida E, Kishi M, Konishi N: Phosphorylation of FADD is critical for sensitivity to anticancer drug-induced apoptosis. Carcinogenesis 2004, 25: I089- 1097.

34. Newton K, Harris AW, Strasser A: FADD/MORTI regulates the pre-TCR checkpoint and can function as a tumour suppressor. Embo / 2000, 19:93 I-94I.

35. Tourneur L, Mistou S, Michiels FM, Devauchelle V, Renia L, Feunteun J. Chiocchia G: Loss of FADD protein expression results in a biased Fas-signaling pathway and correlates with the development of tumoral status in thyroid follicular cells. Oncogene 2003, 22:2795-2804.

36. Michiels FM, Caillou B, Talbot M, Dessarps-Freichey F, Maunoury MT, Schlumberger M, Mercken L, Monier R, Feunteun J: Oncogenic potential of guanine nucleotide stimulatory factor alpha subunit in thyroid glands of transgenic mice. Proc Natl Acad Sci U S A 1994, 9 I: 10488-10492.

37. Tourneur L, Delluc S, Levy V, Valensi F, Radford-Weiss I, Legrand O, Vargaftig J, Boix C, Macintyre EA, Varet B, Chiocchia G, Buzyn A: Absence or Low Expression of Fas-Associated Protein with Death Domain in Acute Myeloid Leukemia Cells Predicts Resistance to Chemotherapy and Poor Outcome. Cancer Res 2004, 64:8101-8108.

38. lijima N, Miyamura K, Itou T, Tanimoto M, Sobue R, Saito H: Functional expression of Fas (CD95) in acute myeloid leukemia cells in the context of CD34 and CD38 expression: possible correlation with sensitivity to chemotherapy. Blood 1997, 90:4901-4909.

39. Buzyn A, Petit F, Ostankovitch M, Figueiredo S, Varet B, Guillet JG Ameisen JC, Estaquier J: Membrane-bound Fas (Apo-I/CD95) ligand on leukemic cells: A mechanism of tumor immune escape in leukemia patients. Blood 1999, 94:3 I35-3140.

40. Laurent G, Jaffrezou JP: Signaling pathways activated by daunorubicin. Blood 200I, 98:913-924.

4I. Friesen C, Fulda S, Debatin KM: Cytotoxic drugs and the CD95 pathway. Leukemia 1999, 13:1854-1858.

42. Wen J, Ramadevi N, Nguyen D, Perkins C, Worthington E, Bhalla K Antileukemic drugs increase death receptor 5 levels and enhance Apo-2L-induced apoptosis of human acute leukemia cells. Blood 2000, 96:3900-3906.

43. Altucci L, Rossin A, Raffelsberger W, Reitmair A, Chomienne C, Gronemeyer H: Retinoic acid-induced apoptosis in leukemia cells is mediated by paracrine action of tumor-selective death ligand TRAIL. Nat Med 200I, 7:680-686

44. Micheau O, Solary E, Hammann A, Dimanche-Boitrel MT: Fas ligand-independent, FADD-mediated activation of the Fas death pathway by anticancer drugs. I Biol Chem 1999, 274:7987-7992.

45. Micheau O, Solary E, Hammann A, Martin F, Dimanche-Boitrel MT: Sensitization of cancer cells treated with cytotoxic drugs to fas-mediated cytotoxicity. I Natl Cancer Inst 1997, 89:783-789.

46. Mullauer L, Mosberger I, Chott A: Fas ligand expression in nodal non-Hodgkin's lymphoma. Mod Pathol 1998, I I:369-375. 
47. Hahne M, Rimoldi D, Schroter M, Romero P, Schreier M, French LE, Schneider P, Bornand T, Fontana A, Lienard D, Cerottini J, Tschopp J: Melanoma cell expression of Fas(Apo-I/CD95) ligand: implications for tumor immune escape. Science 1996, 274:1363-1366.

48. Saas P, Walker PR, Hahne M, Quiquerez AL, Schnuriger V, Perrin G, French L, Van Meir EG, de Tribolet N, Tschopp J, Dietrich PY: Fas ligand expression by astrocytoma in vivo: maintaining immune privilege in the brain? J Clin Invest 1997, 99: I I73- I I 78.

49. O'Connell J, O'Sullivan GC, Collins JK, Shanahan F: The Fas counterattack: Fas-mediated $\mathrm{T}$ cell killing by colon cancer cells expressing Fas ligand. J Exp Med 1996, 184:1075-1082.

50. Strand S, Hofmann WJ, Hug H, Muller M, Otto G, Strand D, Mariani SM, Stremmel W, Krammer PH, Galle PR: Lymphocyte apoptosis induced by CD95 (APO-I/Fas) ligand-expressing tumor cells-a mechanism of immune evasion? Nat Med 1996, 2:136|-I366.

51. Niehans GA, Brunner T, Frizelle SP, Liston JC, Salerno CT, Knapp DJ, Green DR, Kratzke RA: Human lung carcinomas express Fas ligand. Cancer Res 1997, 57:1007-1012.

52. Mitsiades N, Poulaki V, Mastorakos G, Tseleni-Balafouta ST, Kotoula $\mathrm{V}$, Koutras DA, Tsokos M: Fas ligand expression in thyroid carcinomas: a potential mechanism of immune evasion. J Clin Endocrinol Metab 1999, 84:2924-2932.

53. Restifo NP: Not so Fas: Re-evaluating the mechanisms of immune privilege and tumor escape. Nat Med 2000, 6:493-495.

54. Restifo NP: Countering the 'counterattack' hypothesis. Nat Med 200I, 7:259.

55. Favre-Felix N, Fromentin A, Hammann A, Solary E, Martin F, Bonnotte $B$ : Cutting edge: the tumor counterattack hypothesis revisited: colon cancer cells do not induce $T$ cell apoptosis via the Fas (CD95, APO-I) pathway. I Immunol 2000, 164:5023-5027.

56. Desbarats J, Wade T, Wade WF, Newell MK: Dichotomy between naive and memory CD4(+) $T$ cell responses to Fas engagement. Proc Natl Acad Sci U S A 1999, 96:8104-8109.

57. Desbarats J, Newell MK: Fas engagement accelerates liver regeneration after partial hepatectomy. Nat Med 2000, 6:920-923.

58. Freiberg RA, Spencer DM, Choate KA, Duh HJ, Schreiber SL, Crabtree GR, Khavari PA: Fas signal transduction triggers either proliferation or apoptosis in human fibroblasts. J Invest Dermatol 1997, 108:215-219.

59. Owen-Schaub LB, Meterissian S, Ford RJ: Fas/APO-I expression and function on malignant cells of hematologic and nonhematologic origin. J Immunother 1993, 14:234-24I.

60. Mishima K, Nariai Y, Yoshimura Y: Carboplatin induces Fas (APO-I/CD95)-dependent apoptosis of human tongue carcinoma cells: sensitization for apoptosis by upregulation of FADD expression. Int J Cancer 2003, 105:593-600.

61. Micheau O, Tschopp J: Induction of TNF receptor I-mediated apoptosis via two sequential signaling complexes. Cell 2003, II 4:181-190.

\section{Publish with Bio Med Central and every scientist can read your work free of charge}

"BioMed Central will be the most significant development for disseminating the results of biomedical research in our lifetime. "

Sir Paul Nurse, Cancer Research UK

Your research papers will be:

- available free of charge to the entire biomedical community

- peer reviewed and published immediately upon acceptance

- cited in PubMed and archived on PubMed Central

- yours - you keep the copyright

Submit your manuscript here:

http://www.biomedcentral.com/info/publishing_adv.asp
BioMedcentral 